\title{
DETEKSI DAN IDENTIFIKASI KAPANG PADA PROSES BIODETERIORASI ARSIP FOTO MEMORY OF THE WORLD (MOW) RESTORASI CANDI BOROBUDUR
}

\author{
Imam Riadi ${ }^{1}$, Bernadetta Octavia ${ }^{2}$, Mohamad Habibi ${ }^{3}$ \\ 'Mahasiswa Program Studi Biologi Universitas Negeri Yogyakarta, Indonesia. \\ ${ }^{2}$ Dosen Program Studi Biologi Universitas Negeri Yogyakarta, Indonesia. \\ ${ }^{3}$ Peneliti Balai Konservasi Borobudur, Universitas Busan, Korea. \\ imam.riadi2016@uny.ac.id
}

\begin{abstract}
ABSTRAK
Penelitian ini bertujuan untuk mengidentifikasi genus kapang pada proses biodeteriorasi arsip foto Memory of the World $(\mathrm{MoW})$ restorasi Candi Borobudur serta potensi aktivitas enzimatik kapang tersebut. Jenis metode penelitian yang dipilih adalah deksriptif kualitatif. Diawali dengan survey sampling dan pengambilan sampel. Inokulasi kapang menggunakan metode streak pada medium PDA. Identifikasi kapang berdasarkan pengamatan makroskopik dan mikroskopik kapang. Hasil karakterisasi kemudian diidentifikasi dengan metode matching profile menggunakan buku acuan identifikasi kapang. Hasil identifikasi menghasilkan enam genus kapang kontaminan pada biodeteriorasi arsip foto MoW restorasi Candi Borobudur. Genus yang teridentifikasi antara lain: Acremonium (69.66\%\%), Penicillium (14.59\%), Aspergillus (3.36\%), Culvularia (2.24\%) Fusarium (1.12\%), dan Pleurostomophora (1.12\%) dan beberapa miselia steril. Jenis biodeteriorasi pada koleksi foto antara lain: tumbuhnya kapang, bercak perubahan warna, pengelupasan lapisan serta kerusakan substrat pada bagian foto. Berdasarkan penelusuran pustaka semua genus kapang yang ditemukan sebagai penyebab biodeteriorasi sangat berpotensi memiliki enzim proteinase, gelatinase dan selulase.
\end{abstract}

Kata Kunci: Biodeteriorasi; Kapang; Foto; Memory of the World; Candi Borobudur

\section{ABSTRACT}

This study aims to identify the genus of mold in the biodeterioration process of the photo archive of Memory of the World $(\mathrm{Mo} W$ ) restoration of Borobudur Temple and the potential for the enzymatic activity of these molds. The type of research method chosen is descriptive qualitative. Starting with survey sampling and sampling. Inoculation of fungi using the streak method on PDA medium. Mold identification based on macroscopic and microscopic observations of fungi. The results of characterization were then identified using the matching profile method using the mold identification reference book. The identification results resulted in six genera of contaminant molds in the biodeterioration of the MoW photo archive of the Borobudur Temple restoration. The genera identified included: Acremonium (69.66\%\%), Penicillium (14.59\%), Aspergillus (3.36\%), Culvularia (2.24\%) Fusarium (1.12\%), and Pleurostomophora (1.12\%) and some sterile mycelia. The types of biodeterioration in the photo collection include mold growth, discolored spots, peeling off layers, and damage to the substrate in the photo. Based on literature search, all mold genera found as the cause of biodeterioration has the potential to have proteinase, gelatinase, and cellulase enzymes.

Keywords: Biodeterioration; Mold; Photograph; Memory of the World; Borobudur Temple 


\section{PENDAHULUAN}

Candi Borobudur merupakan candi Buddha terbesar di dunia yang masuk dalam daftar daftar warisan dunia (world heritage list) oleh UNESCO pada tahun 1991 (Soekmono, 1978). Candi Borobudur telah mengalami kegiatan restorasi pemugaran sebanyak 2 kali. Kegiatan pemugaran pertama pada tahun 1907-1911, tetapi belum cukup untuk memberikan perlindungan dan rekonstruksi bangunan yang sempurna. Pemugaran kedua pada tahun 1973-1983. Sejak tahun 1973 dilakukan pengumpulan dan perawatan semua arsip penting mengenai pemugaran kedua Candi Borobudur. Arsip ini sangat otentik terkait seluruh aktivitas kegiatan rekam jejak pemugaran pertama dan kedua Candi Borobudur. Saat ini arsip tersebut telah berstatus sebagai arsip Memory of the World (MoW) pada tahun 2017. Koleksi yang tersimpan meliputi 71.851 lembar foto warna dan hitam putih, 6.043 lembar sketsa gambar dan peta konstruksi, 7.024 kaca negatif, 13.512 lembar film positif, 65.741 lembar film negatif, 21 gulungan film seluloid serta 425 dokumen proyek (UNESCO, 2017).

Penelitian yang dilakukan oleh Habibi (2018) serta dari kegiatan pra-penelitian yang telah dilakukan pada Januari 2019 selama tiga minggu ditemukan tumbuhnya kapang pada arsip MoW restorasi Candi Borobudur. Sebagai bentuk pengamanan pada penyimpanan koleksi arsip, adanya kapang pada foto tersebut dapat menimbulkan kerugian secara material karena arsip foto tersebut bernilai sejarah dan sudah ditetapkan sebagai arsip MoW. Oleh karena itu usaha preservasi arsip warisan dunia perlu dilakukan. Salah satu usaha awal preservasi adalah melakukan penelitian untuk mengetahui identitas jenis kapang di arsip MoW restorasi Candi Borobudur. Penelitian ini berusaha untuk mengidentifikasi keanekaragaman kapang dan jenis kerusakan yang ditimbulkan oleh kapang pada arsip foto MoW restorasi Candi Borobudur.

\section{METODE}

Lokasi pengambilan sampel pada ruang arsip MoW restorasi Candi Borobudur dengan lama waktu penelitian mulai bulan Desember 2019 hingga Juni 2020. Jenis penelitian ini adalah deksriptif kualitatif dengan obyek penelitian adalah arsip foto yang mengalami kontaminasi kapang pada arsip MoW restorasi Candi Bororbudur. Teknik dalam menentukan sampel yang digunakan dalam penelitian ini yaitu menggunakan teknik purposive sampling. Purposive sampling yaitu suatu metode penentuan sampel berdasarkan syarat tertentu.

Alat-alat yang digunakan dalam penelitian ini antara lain: buku catatan, korek api, cawan petri, labu spiritus, pipet ukur, tabung reaksi, rak tabung reaksi, jarum ose, erlenmeyer, gelas beker, alat tulis, kamera dslr, mikrometer kalibrasi, termometer, higrometer, kulkas panasonic nr-ak16kd, otoklaf, laminar air flow, heater dan stirrer cimarec, mikroskop olympus, gelas benda, cover glass, gunting, senter, timbangan analitik, gelas kaca kotak, scanner epson 11455, celestron clip view dan oven. Bahan yang digunakan dalam penelitian ini antara lain: media Potato Dextrose Agar (Laboratory grade), kloramfenikol, akuades, alkohol 70\%, plastik wrap, kertas payung, kertas saring, larutan iodin, tisu, plastik sampel, karet gelang, label, cotton swab, solatip, alumunium foil.

\section{Survey Sampling}

Survey sampling arsip dilakukan untuk mengumpulkan informasi tentang karakteristik fisik sampel khususnya mengenai keberadaan arsip yang terkontaminasi oleh mikroorganisme serta untuk menyeleksi koleksi foto yang akan digunakan sebagai sampel. Selanjutnya diseleksi menggunakan metode purposive sampling untuk menentukan arsip foto yang akan digunakan sebagai sampel berdasarkan syarat. Syarat tersebut antara lain: tempat penyimpanan, ukuran, warna, kenampakan miselium, spora pada permukaan (Rakotonirainy, 2007), bercak warna (Komalasari, 2012) dan kerusakan pada substrat. 


\section{Pengukuran Kontaminasi Foto}

Keberadaan kapang yang mengkontaminasi koleksi foto pada arsip perlu diketahui berapa besar tingkat kontaminasi yang terjadi. Oleh sebab itu metode pengukuran yang tepat dan akurat dilakukan dengan menggunakan bantuan fitur measaure area aplikasi Image-J. (Reinking, 2007)

\section{Pengambilan Sampel}

Pengambilan sampel mikroorganisme dari permukaan arsip foto MoW restorasi Candi Borobudur pengambilan sampel menggunakan secara non-destructive dengan teknik swabbing. Pengambilan sampel secara swabbing dilakukan dengan mengoles cotton buds steril pada permukaan substrat kontaminan yang bersifat kering (Ismail et al., 2013), (Borrego et al., 2018). Olesan dilakukan pada luas permukaan $2 \times 2 \mathrm{~cm}^{2}$ selama 30 detik, (Didem et al., 2018). Pengusapan permukaan secara horizontal kemudian secara vertikal (Abbott dan Sean, 2004). Masing-masing sampel foto dilakukan pengambilan sampel pada tiga titik yang berbeda, kondisi permukaan substrat sampel sebelum dilakukan pengambilan dilihat menggunakan kamera celestron clipview.

\section{Isolasi Kapang}

Miselia atau spora dari kapang kontaminan permukaan koleksi foto yang melekat pada cotton swab diinokulasikan pada medium Potato Dextrose Agar (PDA). Cotton swab digoreskan pada media PDA plate secara streak. Kemudian dilakukan inkubasi secara terbalik pada moulds incubator pada suhu $27^{\circ} \mathrm{C}$ selama 7 hari pada kadar kelembaban $70 \%$.

\section{Pemurnian Kapang}

Koloni-koloni kapang yang berfenotip berbeda dimurnikan dengan memindahkan secara aseptik sebagian hifa atau spora kapang ke dalam medium PDA miring $7 \mathrm{ml}$. Pemindahan koloni dilakukan secara bertahap sampai diperoleh isolat murni. Isolat murni kemudian dïnokulasi ke dalam tabung reaksi secara duplo. Satu tabung sebagai working culture untuk proses identifikasi dan karakterisasi dalam inkubator suhu $27^{\circ} \mathrm{C}$ pada kadar kelembaban $70 \%$. Satu tabung sebagai stock culture dalam almari pendingin bersuhu $15^{\circ} \mathrm{C}$.

\section{Identifikasi Kapang}

Isolat kapang yang sudah melalui pemurnian selanjutnya ditumbuhkan pada media PDA untuk pengamatan makroskopis dan mikroskopis karakter fenotip kapang dengan metode slide culture. Pengamatan fenotipe makrokopis kapang yang diamati meliputi warna berdasarkan pada standar warna Faber Castell, tekstur koloni, radial furrow, zonasi, growing zone, exudate drop dan warna sebalik koloni. Pengamatan mikroskopis kapang dilakukan dengan metode slide culture (Tiwari, 2015) meliputi pengamatan konidia, hifa, konidiofor, vesikula, metula dan fialid. Identifikasi kapang tingkat genus (generic assignment) pada proses biodeteriorasi arsip foto MoW dilakukan dengan metode profile matching. Metode profile matching dilakukan dengan membandingkan karakter morfologi makroskopis dan mikroskopis pada beberapa buku identifikasi kapang antara lain Pengenalan Kapang Tropik Umum (Gandjar, 2000), Descriptions of Medical Fungi (Kidd et al., 2016), Fungi: Identification (Richard, 1997), Barnett \& Hunter (1998) serta dari hasil penelitian terkait.

\section{HASIL DAN PEMBAHASAN \\ Survey Sampling}

Berdasarkan total jumlahnya keseluruhan koleksi arsip foto berwarna dan hitam putih terdapat sebanyak 71.851 foto. Dari kelimpahan jumlah koleksi yang tersimpan pada arsip foto MoW restorasi Candi Borobudur untuk dapat lebih tepat sarasan dalam menentukan sampel maka metode pengambilan sampel sangat perlu diperhatikan. Ketepatan metode pengambilan sampel kapang pada suatu obyek merupakan penentu awal keberhasilan untuk mendapatkan isolat kapang yang mengkolonisasi obyek. Dengan demikian apabila dilakukan identifikasi dan karakterisasi dengan benar maka dapat 
memberikan jaminan bahwa isolat kapang tersebut berasal dari sumber obyek yang dimaksudkan.

Foto hitam putih merupakan foto yang mendominasi dari jumlah koleksi foto yang tersimpan serta digunakan sebagai sampel dalam penelitian ini. Setelah dilakukan seleksi sampel foto pada survey sampling menggunakan metode purposive sampling berdasarkan syarat: tempat penyimpanan, ukuran, warna, kenampakan miselium, spora, bercak warna dan kerusakan pada substrat. Hasil dari survey sampling didapatkan sebanyak 238 lembar foto memiliki tanda-tanda biodeteriorasi. Foto yang digunakan sebagai sampel adalah foto dengan kontaminasi diatas $>90 \%$. Selanjutnya tingkat biodeteriorasi diseleksi berdasarkan persentase kontaminasi kapang. Berikut pada gambar 1 menunjukkan proses analisis persentase kontaminasi menggunakan software Image-J.

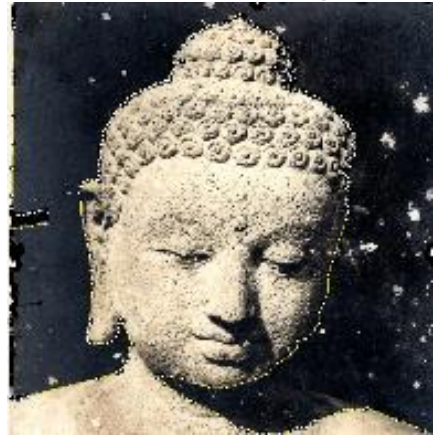

Gambar 1. Analisis persentase kontaminan kapang dengan software Image-J sampel foto 4489916249

(Sumber: Penulis, 2020)

\section{Karakterisasi dan Identifikasi Kapang dengan Profile Matching}

Mikroorganisme teridentifikasi dari arsip foto MoW restorasi Candi Borobudur sebanyak 6 genus, antara lain: Fusarium, Penicillium, Acremonium, Aspergillus, Culvularia dan Pleurostomophora dengan ditemukan adanya beberapa jenis spesies dalam genus Aspergillus dan Penicillium. Kapang yang teridentifikasi sebagian besar termasuk dalam Ascomycota. Kapang terindentifikasi tersebut antara lain:

\section{Fusarium}

Warna permukaan koloni teracotta dengan warna dasar orange glaze, permukaan kapang bertekstur cottony serta tidak terdapat excudate drops lihat gambar 2. Gandjar (2000) miselia aerial tampak seperti kapas kemudian menjadi seperti beludru. Berdasarkan pengamatan mikroskopis hifa berwarna orange tidak dijumpainya adanya vesikula dan metula. Fialid yang pendek serta terdapat belokan kecil (slight bend) sebagai dasar dari konidia baru (Richard, 1997). Hifa bercabangcabang memiliki banyak garis melintang menunjukkan adanya septat antar sel. Hasil pewarnaan bagian hifa dapat terwarnai oleh pewarna lactophenol cotton blue (LCB) menandakan bersifat hialin. Konidiofor memiliki permukaan halus, bercabang, berbentuk silinder panjang 50-100 $\mu \mathrm{m}$ dan lebar 5-10 $\mu \mathrm{m}$.

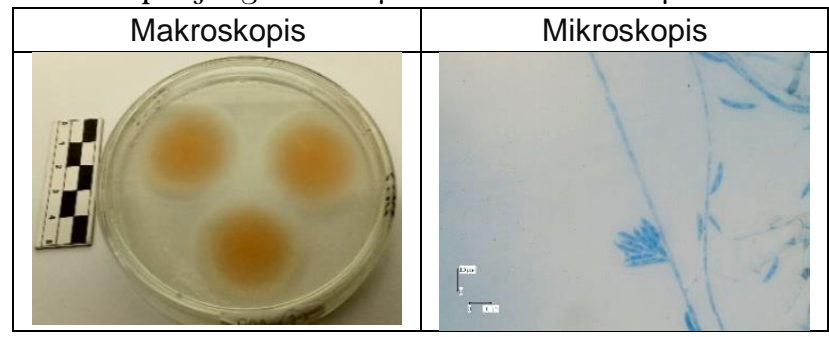

Gambar 2. Isolat kapang Fusarium pada medium PDA (Sumber: Penulis, 2020) 


\section{Penicillium}

Permukaan kapang bertekstur beludru (velvety), warna permukaan koloni deep cobalt green dengan warna dasar cadmium yellow lemon dan terdapat excudate drops berwarna may green lihat gambar 3. Penicillium memiliki karakteristik mikroskopis sebagai berikut : Hifa berwarna putih, berseptat, terdapat metula dan fialid. Konidia tersusun seperti rantai yang memanjang, berbentuk oval, berwarna hialin. Panjang sel konidia 1,5-2,5 $\mu \mathrm{m}$, lebar sel konidia 1,5-2 $\mu \mathrm{m}$ dengan permukaan sel konidia halus. Konidiofor bercabang berdinding halus memiliki panjang 40-100 $\mu \mathrm{m}$, lebar konidiofor 5-10 $\mu \mathrm{m}$. Kompleks konidiofor dan konidia membentuk struktur yang dinamakan branch. Struktur ini membentuk layaknya trisula atau sapu dengan tipe percabangan biververticillate. Pewarnaan sel bersifat hialin serta memiliki septat antar sel.

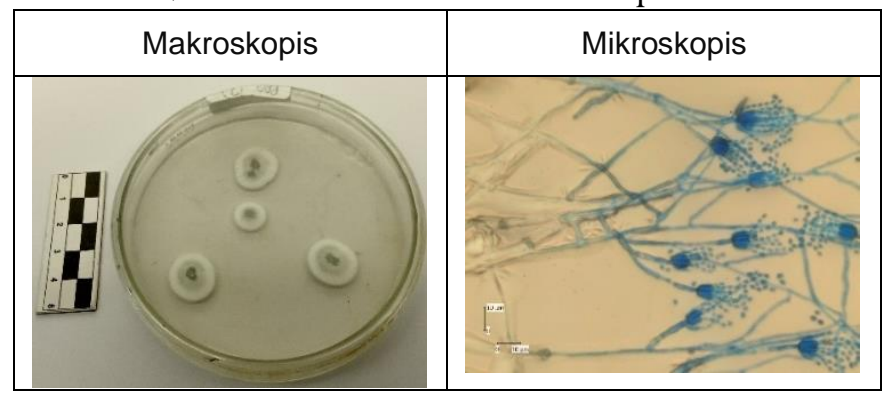

Gambar 3. Isolat kapang Penicillium pada medium PDA

(Sumber: Penulis, 2020)

3. Acremonium

Permukaan kapang bertekstur velvety, warna permukaan warm grey I dengan warna dasar koloni red violet tidak terdapat excudate drops secara jelas dapat dilihat pada gambar 4. Pengamatan secara mikroskopi pada hifa berwarna putih teramati garis melintang menandakan adanya septat, tidak dijumpainya vesikula, metula ataupun fialid, hifa bercabang, hasil pewarnaan bagian dalam dapat terwarnai oleh pewarna LCB menandakan bersifat hialin. Konidiofor memiliki permukaan halus dengan panjang konidiofor 10-50 $\mu \mathrm{m}$ dan lebar konidiofor 1$2 \mu \mathrm{m}$. Konidia berbentuk ellips silindris pendek serta membentuk gugus seperti anggur memiliki permukaan halus dengan panjang dan lebar 1-2 $\mu \mathrm{m}$.

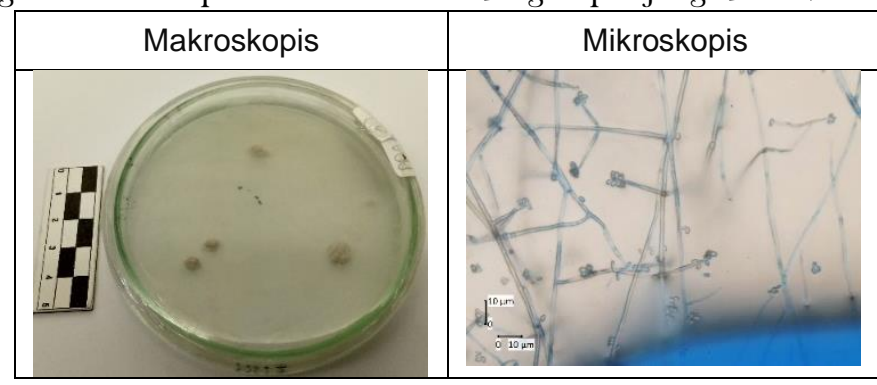

Gambar 4. Isolat kapang Acremonium pada medium PDA

(Sumber: Penulis, 2020)

4. Aspergillus

Secara makroskopi warna permukaan koloni white dengan warna sebalik koloni cream tidak terdapat excudate drops, memiliki permukaan kapang yang bertekstur cottony lihat gambar 5 . Pengamatan secara mikroskopi hifa berwarna putih, konidiofor memiliki permukaan halus dan transparan dengan panjang konidiofor 500-800 $\mu \mathrm{m}$ dan lebar konidiofor 7-10 $\mu \mathrm{m}$. Kepala konidiofor memiliki tipe kepala biseriate. Terdapat vesikula yang besar pada ujung konidiofor, metula mengelilingi permukaan vakuola serta adanya fialid yang 
tumbuh dari struktur metula. Vesikula dapat ditutupi oleh lapisan tunggal terdiri dari fialid (uniseriate) atau dilapisi oleh dua lapisan yang melingkar menutupi vesikula terdiri dari metula dan fialid (biseriate) (Kidd, dkk. 2016). Pada hifa berseptat antar sel serta hifa bercabang. Hifa bersifat hialin, konidia berbentuk globose membentuk rantai dengan permukaan kasar berdiameter 1-3 $\mu \mathrm{m}$.

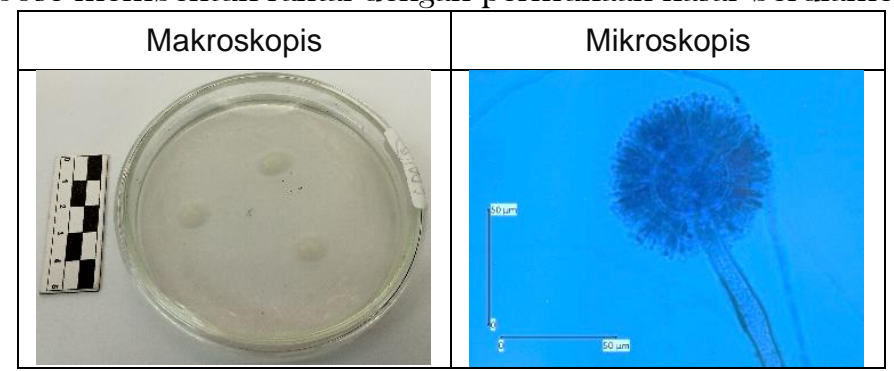

Gambar 5. Isolat kapang Aspergillus pada medium PDA

(Sumber: Penulis, 2020)

5. Culvularia

Isolat memiliki warna permukaan koloni burnt siena dengan warna dasar koloni green gold tidak terdapat excudate drops serta permukaan kapang yang bertekstur downy lihat gambar 6. Pengamatan secara mikroskopi tidak dijumpainya vesikula, metula ataupun fialid. Hifa bercabang berwarna putih, tidak adanya septat antar sel hifa bersifat hialin. Konidiofor memiliki permukaan halus dengan panjang konidiofor 70-100 $\mu \mathrm{m}$ dan lebar konidiofor 2-3 $\mu \mathrm{m}$. Isolat ini memiliki dua tipe konidia yaitu makrokonidia dan mikrokonidia, makrokonidia berbentuk oval memiliki struktur yang disebut porokonidia terdapat 3 septat dengan sel mikronidia kedua dari apeks struktur sel lebih besar dari pada sel mikrokonidia lainnya. Panjang makrokonidia 15-20 $\mu \mathrm{m}$ dan lebar 8-12 $\mu \mathrm{m}$. Mikrokonidia berbentuk oval silindris, permukaan halus panjang 2-3 $\mu \mathrm{m}$ dan lebar $1-2 \mu \mathrm{m}$.

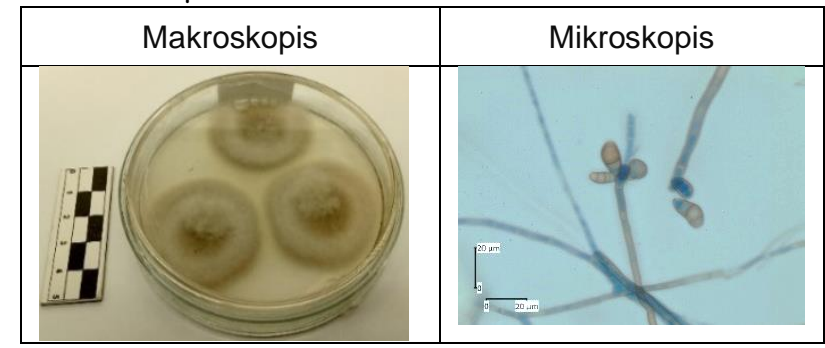

Gambar 6. Isolat kapang Culvularia pada medium PDA

(Sumber: Penulis, 2020)

6. Pleurostomophora

Hasil pengamatan secara makroskopi warna permukaan koloni white dan warna dasar koloni berwarna light green. tidak terdapat excudate drops, memiliki permukaan kapang yang bertekstur downy lihat gambar 7. Pengamatan secara mikroskopi tidak dijumpai adanya vesikula, metula. Fialid berdinding tebal meruncing. Konidiofor memiliki dinding tebal dengan panjang konidiofor 15$30 \mu \mathrm{m}$ dan lebar konidiofor 1-2 $\mu \mathrm{m}$. Hifa berwarna putih tebal bercabang-cabang teramati adanya garis melintang menandakan adanya septat antar sel. Hifa bersifat hialin, konidia tebal berbentuk bulat dengan membentuk rantai zig-zag antar konidia, permukaan halus dengan panjang dan lebar 1.5-2 $\mu \mathrm{m}$. 


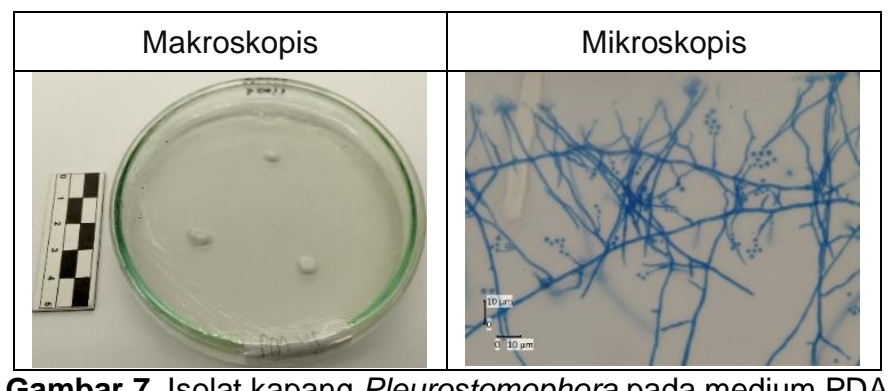

Gambar 7. Isolat kapang Pleurostomophora pada medium PDA

(Sumber: Penulis, 2020)

Persebaran genus kapang yang ditemukan dapat dilihat berdasarkan jumlah dan lokasi ditemukannya. Keberadaan kapang genus Fusarium merupakan kapang yang dijumpai pada foto nomor seri 4489016240 dengan persentase 1.12\% (1). Genus Penicillium terdapat pada foto seri 44890 16240, 33603 7981, 4489916249 dengan persentase 14.59\% (13). Culvularia pada foto seri 336037981 dengan persentase 2.24\% (2). Pleurostomophora pada foto seri 336037981 dengan persentase 1.12\% (1). Selain itu Aspergillus pada foto seri 44890 16240 dengan persentase 3.36\% (3). Persebaran tertinggi didapati oleh genus Acremonium pada foto seri 44890 16240, 33600 7980, 44900 16250, 4489916249 dengan dominasi jumlah sebesar $69.66 \%$ (62) lihat Gambar 8. Sisanya merupakan genus yang belum teridentifikasi sejumlah $7.84 \%$ (7).

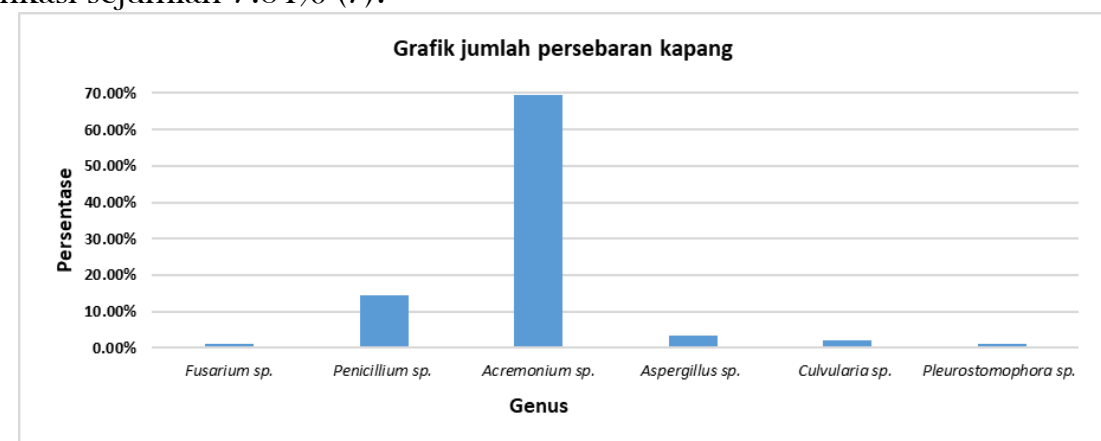

Gambar 8. Grafik persentase kapang di arsip foto MoW Restorasi Candi Borobudur

Genus mikroorganisme serupa juga ditemukan pada penelitian Szulc (2020), mengenai foto berbahan gelatin genus kapang tersebut antara lain: Aspergillus, Alternaria, Penicillium, Chaetomium, Talaromyces dan Fusarium. Penelitian lain oleh Grbic (2013) yaitu genus Fusarium, Humicola, Paecilomyces, Trichoderma, Ulocladium. Penelitian oleh Abrusci (2006) menyebutkan juga genus kapang dari genus Aspergillus, Penicillium, Cladosporium, Alternaria, Mucor, Phoma dan Trichoderma. Pertumbuhan berbagai macam genus kapang pada substrat spesifik seperti gelatin dan selulosa tidak lepas dari kondisi lingkungan yang mendukung dan kemampuan beberapa jenis kapang untuk dapat menggunakan substrat yang ada sebagai sumber nutrisi. Kapang dapat mendegradasi bahan gelatin foto karena beberapa kapang memiliki kemampuan untuk menghasilkan enzim gelatinase serta hifa kapang yang dapat melakukan absorbsi dan penetrasi pada lapisan cetakan fotografi. 


\section{Biodeteriorasi Arsip Foto}

Penelitian yang telah dilakukan oleh Habibi pada tahun 2018, diketahui bahwa struktur penyusun foto gelatin perak yang ada pada koleksi arsip foto MoW restorasi Candi Borobudur antara lain: Substrat kertas, lapisan baryta, lapisan partikel perak dalam gelatin dan lapisan mantel permukaan (Lihat gambar 9).

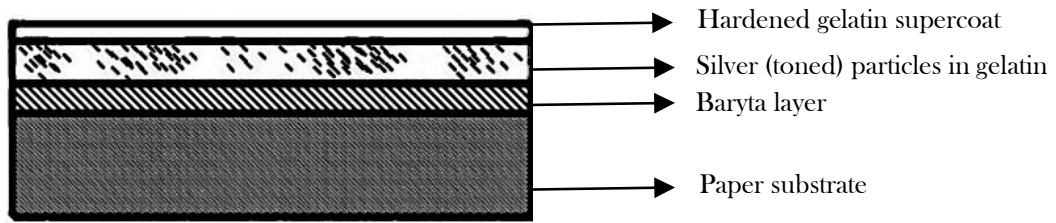

Gambar 9. Skema potongan melintang foto MoW restorasi Candi Borobudur (Habibi, 2018).

Hasil pengamatan Penicillium menggunakan kamera Celestron clip view pada sampel kontaminasi tertinggi. Koleksi foto nomor 4489916249 memperlihatkan pertumbuhan koloni kapang sangat banyak dipermukaan lapisan gelatin foto lihat Gambar 10. Bercak putih terang dengan jumlah yang sangat banyak ditemukan melekat pada lapisan gelatin pengerasan. Pengamatan secara mata telanjang hanya dapat sampai pada kenampakan bercak putih miselium kapang. Kapang dapat mengeksresikan enzim hasil dari metabolisme baik mudah larut maupun sukar larut dalam air (Merritt \& Brewer, 2007). Secara tidak langsung kapang mampu menghasilkan enzim yang dapat menyebabkan terjadinya perubahan struktur kimia di sekeliling rhizoid kapang. Ditandai oleh beberapa sifat keberadaannya yang dapat mengurai bahan organik, menghasilkan pigmen warna, bercak, bau, bersifat allergen dan racun (Service, 2007).

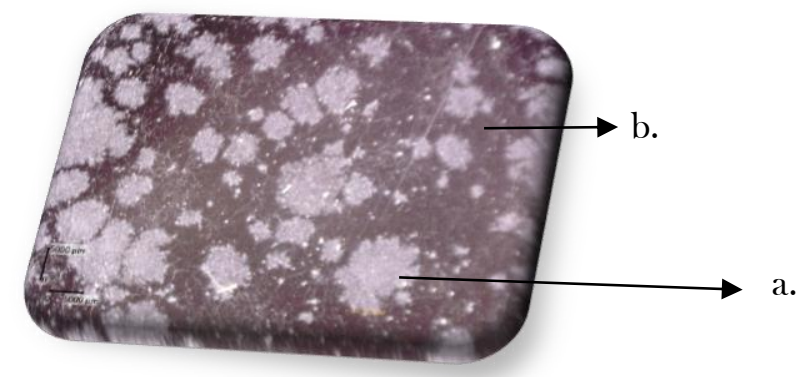

Gambar 10. Koloni kapang pada permukaan gelatin foto; a. Miselium kapang b. Lapisan permukaan gelatin tanpa miselium (Sumber: Penulis, 2020)

Berdasarkan data hasil persebaran genus kapang diketahui bahwa kapang yang mendominasi adalah Acremonium. Acremonium memiliki kemampuan yang lebih adaptif pada kondisi lingkungan dibandingkan genus kapang lainnya. Beberapa strain kapang dapat menyesuaikan diri dengan lingkungan terutama pada fotografi berbahan emulsi perak gelatin lihat Gambar 11. Hal lain yang menjadi dugaan kuat pada serangan kapang dibahan fotografi ini adalah resistensi dan kemampuan kapang dalam biosorpsi nutrisi dari lapisan gelatin perak kedalam hifa kapang. Sclocchi et al., (2012) membuktikan bahwa kapang (Aspergillus dan Penicillium) penyebab kerusakan foto mampu mengurangi ion perak dengan membentuk nanopartikel perak di dinding sel yang dibatasi oleh balutan protein struktural. Tingginya keberadaan nilai sulfur (S) dan magnesium $(\mathrm{Mg})$ di sekeliling perak di permukaan dinding sel menunjukkan adanya balutan protein yang membantu kapang menyerap perak pada bahan fotografi. 


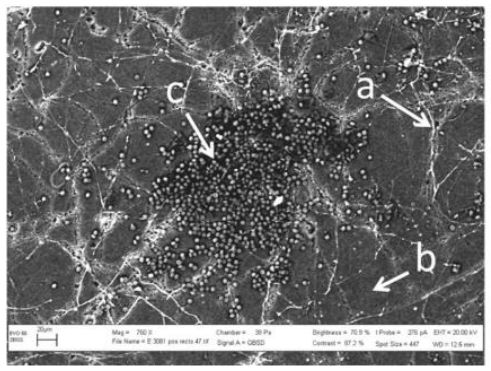

Gambar 11. Biosorpsi partikel perak dari lapisan gelatin perak ke hifa kapang a. Akumulasi Ag pada hifa, b. Area kosong tanpa kerusakan gelatin, c. Konidia (Sclocchi et al., 2012)

Perbandingan pola pertumbuhan kapang pada foto berwarna hitam dan putih menunjukan pada area putih lebih mudah untuk ditumbuhi kapang. Area foto bewarna hitam memiliki konsentrasi partikel perak yang tinggi dibanding area warna putih. Lourenco, (2007) menjelaskan pertumbuhan kapang pada area warna putih lebih luas pertumbuhannya dari pada area gambar hitam karena rendahnya keberadaan partikel perak. Sedangkan sporulasi lebih banyak pada area warna hitam karena kapang dalam kondisi tekanan lingkungan (keracunan) menunjukan hubungan tingginya keberadaan partikel perak pada area warna hitam.

\section{Perawatan Arsip Foto}

Kondisi klimatis yang dialami oleh arsip foto pada ruang penyimpanan arsip sebelum dilakukan renovasi tercatat pada rentang suhu $26.37^{\circ} \mathrm{C} \sim 31.97^{\circ} \mathrm{C}$ dengan rata-rata suhu ruang $29.58^{\circ} \mathrm{C}$, kelembaban ruang pada rentang $46.82 \% \sim 79.88 \%$ dengan kelembaban relatif $65.92 \%$ dapat dilihat pada Gambar 12.

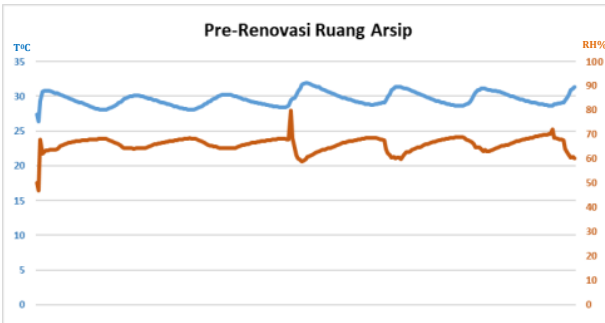

Gambar 12. Grafik klimatis pre-renovasi ruang arsip

Suhu dan kelembaban relatif arsip foto pada penyimpanan sebelum renovasi ruang arsip tidaklah sesuai dengan standar penyimpanan pada semestinya. Hal ini sangat menghawatirkan terhadap potensi pertumbuhan kapang pada arsip karena sangat memungkinkan tumbuhnya kapang pada kondisi optimum serta potensi jenis kerusakan lain yang dapat terjadi. Kondisi klimatis penyimpanan pasca renovasi berkisar pada rentang $14.17^{\circ} \mathrm{C} \sim 19.37^{\circ} \mathrm{C}$ dengan suhu rata-rata $14.91^{\circ} \mathrm{C}$, kelembaban ruang penyimpanan pada rentang $67.97 \% \sim 100 \%$ dengan kelembaban relatif $74.38 \%$. Secara umum klimatis tempat peyimpanan telah mengalami banyak perubahan. Kondisi suhu saat ini lebih stabil serta mendekati standar klimatis ideal penyimpanan arsip fotografi, akan tetapi kelembaban relatif yang masih tinggi sehingga sangat memungkinkan untuk pertumbuhan dan perkecambahan kapang. Kondisi klimatis yang terjadi setelah renovasi ruang arsip dapat dilihat pada Gambar 13. 


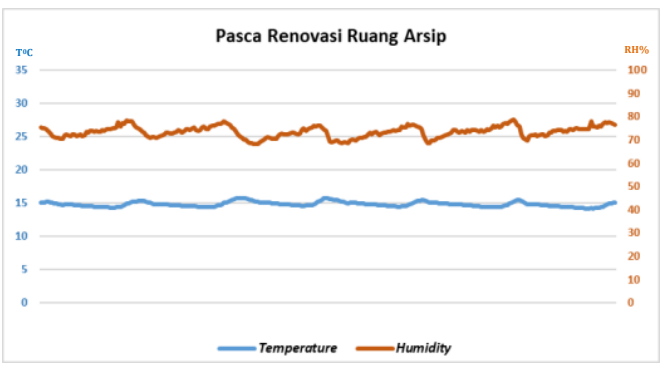

Gambar 13. Grafik klimatis pasca renovasi ruang arsip

Harapan yang lebih baik bahwa untuk kedepannya dapat ditekan lebih rendah lagi kelembaban relatif ruang penyimpanan arsip sehingga penyimpanan koleksi foto dapat dilakukan seperti berdasarkan rekomendasi dari british library dan lembaga Arsip Nasioal Republik Indonesia, standar suhu dan kelembaban yang dipersyaratkan bagi penyimpanan jenis arsip fotografi hitam putih suhu $17^{\circ} \mathrm{C} \pm 2^{\circ} \mathrm{C}$, kelembaban $35 \pm 5 \%$. Hal yang dilakukan pada Indiana Historical Society-USA menerapkan pada suhu $10^{\circ} \mathrm{C}$ dan relative humidity (RH) $35 \%$. Museum Seni Amerika - Amon Carter pada penyimpanan sejuk suhu $15 \pm 3^{\circ} \mathrm{C}$, RH $40 \%$ pada penyimpanan dingin $-7^{\circ} \mathrm{C}$, RH $30 \%$ dan ruang depan untuk aklimatisasi foto (Panadero, 2019).

\section{KESIMPULAN}

Kapang yang teridentifikasi sebagai kapang kontaminan penyebab biodeteriorasi pada sampel arsip foto Memory of the World restorasi Candi Borobudur adalah genus: Acremonium (69.66\%\%), Penicillium (14.59\%), Aspergillus (3.36\%), Culvularia (2.24\%) Fusarium (1.12\%), dan Pleurostomophora (1.12\%). Koleksi foto pada arsip Memory of the World restorasi Candi Borobudur menunjukan terjadinya biodeteriorasi. Koloni kapang yang ditemukan dipermukaan cetakan foto terlihat jelas dan berlimpah penyebab bercak perubahan warna, pengelupasan lapisan serta kerusakan substrat foto. Genus kapang yang ditemukan penyebab biodeteriorasi sangat berpotensi memiliki enzim proteinase, gelatinase dan selulase.

\section{SARAN / REKOMENDASI}

Beberapa hal yang perlu menjadi pertimbangan berdasarkan penelitian ini antara lain:

1. Perlu dilakukan penelitian lebih lanjut mengenai identifikasi molekuler dan uji aktivitas enzim pada kapang yang ditemukan sehingga dapat menjelaskan lebih rinci terjadinya biodeteriorasi arsip foto.

2. Diperlukan penelitian lanjutan pencegahan dan pengendalian yang efektif koleksi foto dari kontaminasi kapang.

3. Pemberian kerapatan yang cukup antar koleksi foto agar tidak terjadi tekanan antar arsip yang berdekatan.

4. Standar klimatis penyimpanan berada pada suhu $17 \pm 2^{\circ} \mathrm{C}$ serta kelembaban $35 \pm 5 \%$ dengan variasi perubahan (maksimum dalam $24 \mathrm{jam}$ ) suhu $\pm 2^{\circ} \mathrm{C}$ dan kelembaban $\pm 5 \%$.

5. Penambahan UV filter pada perangkat pencahayaan.

6. Pengunjung, Konservator, Pustakawan atau Arsiparis yang berhubungan dengan foto restorasi Candi Borobudur yang berharga ini harus selalu mematuhi standar protokol keamanan kerja dan kesehatan. 


\section{UCAPAN TERIMA KASIH}

Terimakasih saya ucapkan kepada Mohamad Habibi S.Si, Nahar Cahyandaru M. Sc dan Dr. Dra. Bernadetta Octavia, M.Si yang telah banyak memberikan sumbangsih ilmu dan arahan pada penulis.

\section{DAFTAR PUSTAKA}

Abbott, S. P. (2004). Fungal Sampling Methods. Natural Link MOLD LAB, Inc.

Abrusci, C., Marquina, D., Del Amo, A., Corrales, T., Catalina, F. (2006). A viscometric study of the biodegradation of photographic gelatin by fungi isolated from cinematographic films. Int. Biodeter. Biodegr. 58, 142e149.

Barnett, H. L. \& B. B. Hunter. (1998). Illustrated Genera of Imperfect Fungi fourth edition. APS Press. The American Phytopathological Society USA.

Borrego, S., Patricia, G. S., Vivar, I., Battistoni, P. (2018). Fungi Involved in Biodeterioration of Documents in Paper and Effect on Substrate. UNLP, La Plata, Argentina. Acta Microscopica. 27: 37-44

Gandjar, I., R.A. Samson, K. van den Tweel-Vermeulen, A. Oetari, \& I. Santoso. (2000). Pengenalan Kapang Tropik Umum. Yayasan Obor Indonesia. Jakarta: xiï ${ }^{+}$ 126 halaman.

Habibi, Mohamad. (2018). Conservation of Photographic Paper Collections Using Essential Oils. Daejeon, Korea

Ismail, R., Aviat, F., Michel, V., \& Bayon, I. Le. (2013). Methods for Recovering Microorganisms from Solid Surfaces Used in the Food Industry: A Review of the Literature. 6169-6183. https://doi.org/10.3390/ijerph10116169

Kidd, S. Halliday, C. Alexiou1, H dan Ellis, D. (2016). Descriptions of Medical Fungi, Third Edition. University of Adelaide. Australia.

Komalasari, Dessy. (2012). Isolasi, Identifikasi dan Pengujian Kemampuan Kapang Selulolitik Dari Naskah Kuno Kertas Eropa Asal Keraton Kasepuhan Cirebon. Skripsi: Universitas Indonesia.

Lourenco, M. J. L \& Sampaio J.P. (2007). Microbial Deterioration of Gelatin Emulsion Photographs: A Case Study. Volume 12. 19-34

Merritt, J. \& T. Brewer. (2007). Mold: Prevention of Growth in Museum Ccollections. Conserve O Gram 3(4): 1--5.

Panadero, Laura. (2019). On presentation of Amon Carter Museum of American Art 3year cold storage expansion project. Fernanda Valverde. American Institute for Conservation 47th annual meeting.

Rakotonirainy, M. S., Heude, E., \& Lave, B. (2007). Isolation and Attempts of Biomolecular Characterization of Fungal Strains Associated to Foxing on a 19th 
Century Book. (December 2017). https://doi.org/10.1016/i.culher.2007.01.003

Reinking, L. 2007. ImageJ Basic. Department of Biology, Millersville University. www.melville.ch.cam.ac.uk.

Richard, A H. (1997). Fungi: Identification. Journal Manual of Techniques In Insect Pathology. USDA-ARS Plant Protection Research Unit. New York: USA. Chapter V- 1. ISBN 0--12-432555-6.

Sclocchi, M.C, Damiano, E. Matè, D. Colaizzi, P. Pinzari, F. (2012). Fungal Biosorption of Silver Particles on 20th-Century Photographic Documents. International Biodeterioration Biodegredation. 84 367-371.

Service, National Park. 2007. Mold: Prevention of Growth in Museum Collections. Conserve O Gram. Washington, USA

Soekmono, R. DR. (1978). Candi Borobudur - Pusaka Budaya Umat Manusia. Jakarta: Pustaka Jaya.

Tiwari, K. (2015). The Future Product: Endophytic Fungal Metabolites. Departemen Mikrobiologi, Managemen dan Sains Universititas Shah Alam. Malaysia.

UNESCO. (2017). Borobudur Conservation Archieves-Memory of the World. http://www.unesco.org/new/fileadmin/MULTIMEDIA/HQ/CI/CI/pdf/mow/ nomination_forms/indonesia_borobudur_eng.pdf 